\title{
Anti-tumor Effects of Essential Oils of Red Clover and RagWeed on MCF-7 Breast Cancer Cell Line
}

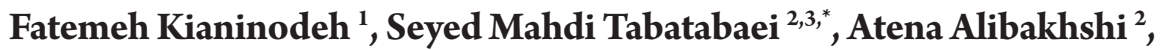 \\ Mahshid Gohari ${ }^{2}$, Kaveh Tari ${ }^{4}$ \\ ${ }^{1}$ High Institution for Research and Education in Transfusion Medicine, Tehran, Iran \\ ${ }^{2}$ Department of Laboratory Sciences, College of Science of Borujerd, Islamic Azad \\ University, Iran \\ ${ }^{3}$ Young Researchers and Elite Club, Borujerd Branch, Islamic Azad University, \\ Borujerd, Iran \\ ${ }^{4}$ Cancer and Immunology Center, Kurdistan University of Medical Sciences Sanandaj, \\ Iran \\ * Corresponding author: Seyed Mahdi Tabatabaei, Department of Laboratory Sciences, \\ College of Science of Boroujerd, Islamic Azad University, Iran. E-mail: Mahdi.tabat- \\ abaei96@gmail.com
}

DOI: $10.21859 / \mathrm{mci}-01043$

Submitted: 2 August 2017

Revised: 3 September 2017

Accepted: 28 September 2017

ePublished: 1 October 2017

\section{Keywords:}

Bassia Scoparia

Red Clover

Cell Viability

\begin{abstract}
Introduction: Breast cancer is one of the most common malignancies among Iranian women. Nowadays, the use of traditional medicinal plants has emerged as a tempting complementary to the treatment of breast cancer due to minimal side effects and less documented drug resistance. The aim of this study was to examine the anticancer effects of the essential oils of red clover and mature fruit of Bassia scoparia on MCF-7 cells.

Methods: Essential oils were extracted from Bassia scoparia and red clover plants, by a Clevenger condenser and mass spectrometry was performed for qualitative analysis, then MCF-7 and HU02 cells were treated with different concentrations of these essential oils at different time intervals. The viability of cells was measured by the MTT assay. The results were analyzed using the one-way ANOVA and Tukey's test.

Results: Essential oils of Kochia scoparia and red clover have cytotoxic effects on MCF7 cells. The MTT analysis showed decreased cell viability percentage in treated cells ( $\mathrm{P}$ $<0.05)$. In addition, the microscopic examination of cells treated with essential oils revealed morphological changes of apoptotic cells in MCF-7 cells.

Conclusions: The findings of this study show that essential oils of Bassia scoparia and Red clover have toxic and anticancer effects on MCF-7 cells.
\end{abstract}

(C) 2017. Multidisciplinary Cancer Investigation

\section{INTRODUCTION}

Breast cancer is the most common invasive cancer in women. It is the leading cause of death worldwide and accounts for about $18 \%$ of cancer cases in women. The incidence of this cancer is much higher in developed countries compared to developing countries, which is associated with multiple reasons. The life expectancy is probably one of these causes, and lifestyle, dietary habits, fertility, environment, and physical activity play important roles in the incidence of breast cancer as well. Several systemic chemotherapeutic agents such as 5-fluorouracil, trastuzumab, cyclophosphamide, doxorubicin, bevacizumab, and tamoxifen are used to treat this disorder. However, despite their anticancer effects, these drugs have adverse side effects such as cardiac toxicity, bone marrow failure, thrombocytopenia, and mucositis. Therefore, the use of novel and more effective drugs with minimum side effects, including traditional herbal drugs and natural substances, may be useful to prevent the development and progression of breast cancer $[1,2]$. Red clover (Trifolium pratense L.) is one of the forage plants belonging to the Trifolium species of the leguminous family. It grows in temperate and humid regions and plays an important role as livestock feed. Its flowers have a sweet and delicious flavor and have been traditionally used as a seasoning in salads, soups, desserts, and beverages all over the world [3]. This plant contains flavonoids, coumarins, coumestans, and isoflavones, which can be used orally or topically. Red clover is believed to be effective in the treatment of cancers related to hormonal disorders. It is also used to reduce the rate of hot flushes in women with premature menopause as part of their cancer treatment. Early studies have also shown that isoflavones in red clover may be useful in treating prostate and colon cancers, but there 
is still insufficient evidence in this regard [4].

Bassia scoparia fruit is an annual plant of Chenopodiaceae family, which is usually harvested in autumn and dried in the sun throughout China. It is widely used as a medicinal plant for treating dysuria and skin disease in China and Japan. Bassia scoparia has particularly been used for the treatment of breast masses and chest pain. Various types of compounds, including triterpenoid glycosides, saponins, and alkaloids have been isolated from this herb. Furthermore, the anti-inflammatory and anti-allergic effects of $K$. scoparia have been demonstrated. Recently, it was reported that Bassia scoparia fruit also has potential antitumor effects, but its anticancer mechanism has not been determined [5]. Hey Yeon Han et al. showed that the methanol extracted from the dried fruit of $K$. scoparia (MEKS) inhibits cell proliferation and induces apoptosis in MDA-MB-231 breast cancer cell line [6]. They also showed the apoptotic effect of essential oil of K. scoparia fruit on oral squamous cell carcinoma (OSCC) cell line using the MTT method [7]. In this study, the possible cytotoxic and anticancer effects of $K$. scoparia and red clover on the MCF-7 breast cancer cell line were investigated.

\section{METHODS}

\section{The MCF-7 and HUO2 Cell Lines}

The MCF-7 cell line (a breast cancer cell line) and HUO2 (a human fibroblast cell line) were purchased from $\mathrm{Na}$ tional Center of Genetic and Biological Reserves of Iran. Cell culture materials were purchased from Gibco Company (USA), but the flasks and microplates were acquired from Griner Company (Germany).

\section{Collection of Plant Samples}

The samples of Trifolium pratense L. and Bassia scoparia, which were harvested from Boroujerd city of Lorestan Province, were confirmed by Faculty of Natural Science, and deposited at the Herbarium of the Department of Boroujerd Islamic Azad University. Next, the collected plant materials were dried in a dark place and after drying were packed in paper bags in which they were preserved until the experiments were conducted.

\section{Essential Oil Extraction}

The selected method to isolate essential oils is dependent upon the original composition of the plant (alkaloids, flavonoids, terpenes, and sugars) as well as the purity degree of the final product. In this study, a Clevenger condenser was used for the extraction of essential oils using distillation. First, $20 \mathrm{~g}$ of a chopped and dried sample from both plants' leaves were placed in the flask $(1000 \mathrm{~mL})$ and $400-500 \mathrm{~mL}$ distilled water was added to it. Before extraction, the trays were washed with ace- tone, water, alcohol, and eventually water, respectively. Next, the water temperature was increased to boiling temperature. Heating continued until the first drop of liquid appeared in G-part at the end of the cooling part. Consequently, the essential oil was collected and kept in sealed bottles in the refrigerator $\left(+4^{\circ} \mathrm{C}\right)$. This process lasted 3-5 hours.

\section{Mass Spectrometry}

Qualitative analysis was performed using an Agilent 7980 gas chromatograph (GC) equipped with an Agilent 5975C mass selective detector (MS). The MS detector was operated in the electron impact system with the interface temperature of $280^{\circ} \mathrm{C}$. Also, the IE source temperature was set to $150^{\circ} \mathrm{C}$, analyzer temperature was set to $230^{\circ} \mathrm{C}$, and interface temperature between GC and MS was set on $420^{\circ} \mathrm{C}$.

\section{Cell Culture}

In this experimental study, MCF-7 and HU02 cells were grown in a RPMI-1640 medium supplemented with 10\% Fetal Bovine Serum (FBS), $2 \mathrm{mM} / \mathrm{L}$ glutamine, $100 \mathrm{unit} / \mathrm{mL}$ penicillin, and $100 \mu \mathrm{g} / \mathrm{mL}$ streptomycin in a 5\% CO2 incubator (Memmert) at a temperature of $37^{\circ} \mathrm{C}$ under standard cell culture conditions.

\section{Cell Viability Measured by the MTT Assay}

The effects of different concentrations of Bassia scoparia and Trifolium pratense $L$. on cell viability were examined by the MTT [3-(4,5-dimethyl-2-thiazolyl) -2, 5-diphenyl $-2 \mathrm{H}$ - tetrazolium bromide] colorimetric method. Briefly, the cells were put into a 96-well culture plate at a density of 10000 cells/well and incubated with various concentrations of $K$. scoparia and Trifolium pratense $L$. for $24 \mathrm{~h}$. After removing the culture medium, the cells were incubated with MTT solution ( $5 \mathrm{mg} / \mathrm{mL}$ in PBS) for 3 hours, and the resulting formazan was solubilized using 150-200 $\mu \mathrm{L}$ of DMSO (Sigma). The absorbance was measured at $570-590 \mathrm{~nm}$ in a plate reader (BioTeK ELx800).

\section{Microscopic Examination}

The effects of different concentrations of essential oils of Bassia scoparia and red clover on morphology of MCF-7 and HU02 cells were examined by microscopic observation. For this purpose, first the cells were treated with various concentration of essential oils of Bassia scoparia and red clover for 24, 48 and 72 hours. Then, the morphological changes were examined by an invert microscope (Olympus).

\section{Statistical Analysis}

The SPSS 20 software was used to perform statistical analyses. The significance of differences between the ex- 
perimental variables was determined using the one-way ANOVA analysis and Tukey's test. A probability level of $\mathrm{P}<0.05$ was considered as statistically significant.

\section{RESULTS}

$2 \mathrm{~mL}$ of essential oils was extracted from $400 \mathrm{~g}$ dried leaves of $K$. scoparia and red clover by the distillation method. The results of extraction were analyzed using the GC/MS mass spectrometry and are presented in Table 1 and 2. According to these results, the main compounds in the essential oil of K. scoparia included $\alpha$-thujaplicin, phytoene, butylated hydroxytoluene, dictamnol, phytol, n-docosane and the important compounds of red clover were hexanal 2-ethylfuran, 2-methyl-2, 4-hexadiene, and cyclopentanol.

Table 1: Essential Oil Composition of Aerial Parts of Red Clover Samples Collected in Boroujerd

\begin{tabular}{lccc}
\hline Number & Contents (Shoot) & Area & RT (min) \\
\hline $\mathbf{1}$ & Isobutane & 1847771 & 1.89 \\
$\mathbf{2}$ & Methoxyformamide & 1523033 & 1.97 \\
$\mathbf{3}$ & Pentanal & 552258 & 2.701 \\
$\mathbf{4}$ & 2-propen-1-ol & 706088 & 2.814 \\
$\mathbf{5}$ & Cyclopentanol & 116639 & 3.078 \\
$\mathbf{6}$ & 2-ethylfuran & 216453 & 3.357 \\
$\mathbf{N u m b e r}$ & Contents (Flower) & Area & $\mathbf{R T}(\mathbf{m i n})$ \\
$\mathbf{1}$ & Isobutane & 2146156 & 1.826 \\
$\mathbf{2}$ & Methoxyformamide & 3610489 & 1.974 \\
$\mathbf{3}$ & Pentanal & 1254088 & 2.699 \\
$\mathbf{4}$ & 2-propen-1-ol & 3608496 & 2.812 \\
$\mathbf{5}$ & 2-methyl-2,4-hexadiene & 221914 & 3.344 \\
$\mathbf{6}$ & Hexanal & 247138 & 6.165 \\
\hline
\end{tabular}

Table 2: Essential Oil Composition of K. scoparia Samples Collected in Boroujerd

\begin{tabular}{|c|c|c|c|}
\hline Number & Contents & Area & $\mathrm{RT}(\mathrm{min})$ \\
\hline 1 & n-eicosane & 2000 & 2.61 \\
\hline 2 & $n$-henicosane & 2100 & 3.1 \\
\hline 3 & $n$-docosane & 2200 & 3.17 \\
\hline 4 & $n$-tricosane & 2300 & 1.23 \\
\hline 5 & $n$-tetracosane & 2400 & 1.87 \\
\hline 6 & Isopropyl tiglate & 976 & 0.91 \\
\hline 7 & n-decane & 999 & 0.66 \\
\hline 8 & P-methyl anisol & 1019 & 0.43 \\
\hline 9 & Camphenilone & 1082 & 2.11 \\
\hline 10 & Maltol & 1108 & 2.09 \\
\hline 11 & $Z$-damascone & 1358 & 2.33 \\
\hline 12 & Orcinol & 1371 & 0.92 \\
\hline 13 & $E$-damascenone & 1385 & 1.12 \\
\hline 14 & O-methyl eugenol & 1401 & 1.33 \\
\hline 15 & $\alpha$-thujaplicin & 1412 & 16.89 \\
\hline 16 & Dictamnol & 1430 & 6.51 \\
\hline 17 & Butylated hydroxytoluene & 1512 & 7.49 \\
\hline 18 & $n$-hexadecane & 1600 & 0.76 \\
\hline 19 & 2,6,10,-tetramethylpentadecane & 1688 & 0.64 \\
\hline 20 & $n$-heptadecane & 1700 & 1.49 \\
\hline 21 & Phytone & 1790 & 9.11 \\
\hline 22 & $n$-octadecane & 1800 & 0.56 \\
\hline 23 & Phytoene & 1815 & 1.19 \\
\hline 24 & $n$-nonadecane & 1900 & 2.92 \\
\hline 25 & Phytol & 1943 & 5.51 \\
\hline 26 & Isophytol & 1948 & 0.98 \\
\hline
\end{tabular}




\section{Essential Oils of Red Clover and K. scoparia Cause Morphologic Changes in MCF-7 Cells}

The morphological changes related to essential oils of red clover and K. scoparia fruit on the MCF-7 cancer cell line and natural HU02 fibroblast cell line were examined by microscopic observation after treatment of these cells with different concentrations of essential oils for 24, 48, and 72 hours. As shown in figure 1, the HU02 cells treated with different concentrations of essential oils of red clover and K. scoparia showed no significant morphological changes as compared to control cells. These results showed that the essential oils of red clover and K. scoparia had no effect on control cells while morphological changes in the treated MCF-7 cancer cells were significant as compared with MCF-7 control cells. As shown in figure 1, morphological changes are visible as star-like shapes, vacuolation, cytoplasmic and cellular shrinkage as well as pyknotic nuclei, which are attributes of apoptotic cells. These observations indicated the cytotoxic effects of essential oils of red clover and $\mathrm{K}$. scoparia on MCF-7 cancer cells. Interestingly, as shown in figure 1 , the observed morphological changes were more frequent and obvious with increasing dose and duration of cell treatment by essential oils of red clover and K. scoparia, indicating the toxic effects of these essential oils in a dose- and time-dependent manner on MCF-7 cancer cell lines.

\section{Red Clover Essential Oil Induced Cell Death in MCF-7 Cells}

The viability of MCF-7 cells was assessed by the MTT assay after treatment of cells with various concentrations of red clover's essential oil for 24, 48, and 72 hours, as shown figure 2 Next, the cells were stained using MTT solution (containing tetrazolium salt), and the absorbance was finally measured by an ELISA reader. As presented in figure 2 , the cytotoxic effect of the essential oil of red clover on MCF-7 cells was dose- and time-dependent. In addition, it was indicated that the percentage of viable cells was significantly decreased $(\mathrm{P}<0.05)$ at 15 and $30 \mu \mathrm{g} / \mathrm{mL}$ concentrations of essential oils of red clover. Table 3 shows the results related to one of the triplicate mean cell viability assays as mean \pm standard deviation (Mean \pm SD). Moreover, the minimum inhibitory concentration (IC50) value of red clover's essential oil on growth of MCF-7 cells was observed in $125 \mu \mathrm{g} / \mathrm{mL}$ concentration. The percentage of viable cells treated with red clover's essential oil was calculated using the following formula as compared with control cells:
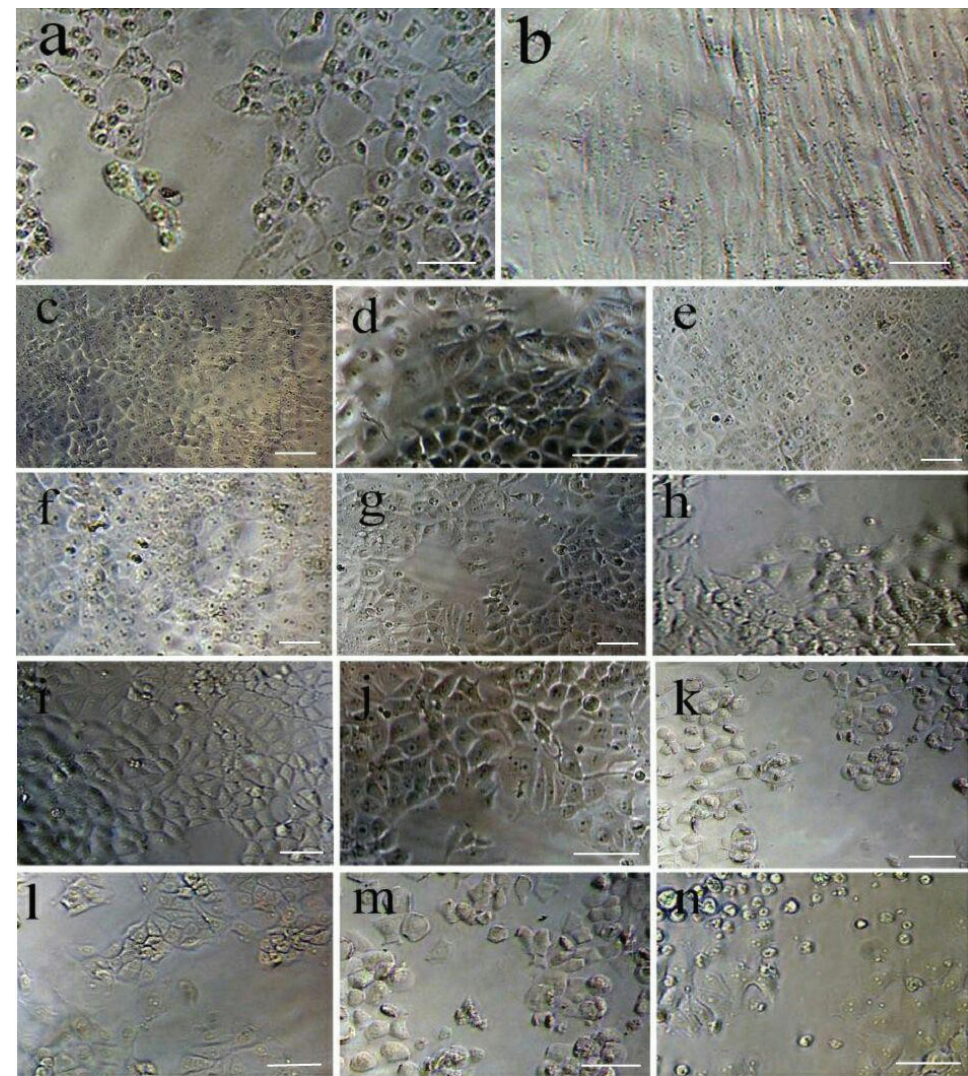

Figure 1: Morphologic Changes in MCF-7 and HU02 Cells Treated with Essential Oils with a Dose of 100 $\mu \mathrm{g} / \mathrm{mL}$ of Red Clover and K. scoparia.

a: MCF-7 control cells; b: HU02 cells; c-e: MCF-7 cells treated with red clover essential oils; f-h: MCF-7 cells treated with K. scoparia essential oils; i-k: MCF-7 cells treated with red clover essential oils, l-n: MCF-7 cells treated with broom grass essential oils within 24, 48, and 72 hours.

All the pictures have a 50-micrometer scale bar. 
Table 3: Test Results of One of the Triplicate Mean Cell Viability Tests for MCF-7 Cells After Incubation with Red Clover's Essential Oil as Mean \pm SD

\begin{tabular}{lcccccc}
\hline Time (hour) & Control & $\mathbf{1 5} \boldsymbol{\mu g} / \mathbf{m l}$ & $\mathbf{3 0} \boldsymbol{\mu g} / \mathbf{m l}$ & $\mathbf{6 0} \boldsymbol{\mu g} / \mathbf{m l}$ & $\mathbf{1 2 5} \boldsymbol{\mu g} / \mathbf{m l}$ & $\mathbf{2 5 0} \boldsymbol{\mu g} / \mathbf{m l}$ \\
\hline $\mathbf{2 4}$ & 100 & $97.83 \pm 1.44$ & $88.42 \pm 1.95$ & $62.51 \pm 1.73$ & $57.63 \pm 0.91$ & $47.33 \pm 0.17$ \\
$\mathbf{4 8}$ & 100 & $93.18 \pm 0.55$ & $81.33 \pm 0.63$ & $61.05 \pm 0.11$ & $54.19 \pm 1.78$ & $47.19 \pm 0.54$ \\
$\mathbf{7 2}$ & 100 & $90.34 \pm 0.21$ & $69.73 \pm 1.49$ & $60.48 \pm 0.77$ & $51.88 \pm 1.41$ & $47.05 \pm 1.83$ \\
\hline
\end{tabular}

Table 4: Test Results of one of the Triplicate Mean Cell Viability Tests for MCF-7 Cells After Incubation with Essential Oil of K. scoparia as Mean \pm SD

\begin{tabular}{lcccccc}
\hline Time (hour) & Control & $\mathbf{1 5} \boldsymbol{\mu g} / \mathbf{m l}$ & $\mathbf{3 0} \boldsymbol{\mu g} / \mathbf{m l}$ & $\mathbf{6 0} \boldsymbol{\mu g} / \mathbf{m l}$ & $\mathbf{1 2 5} \boldsymbol{\mu g} / \mathbf{m l}$ & $\mathbf{2 5 0} \boldsymbol{\mu g} / \mathbf{m l}$ \\
\hline 24 & 100 & $95.35 \pm 0.82$ & $73.69 \pm 0.34$ & $59.83 \pm 0.25$ & $46.2 \pm 0.98$ & $41.9 \pm 1.53$ \\
48 & 100 & $89.22 \pm 0.76$ & $68.83 \pm 0.80$ & $53.7 \pm 0.12$ & $45.66 \pm 0.36$ & $38.16 \pm 0.77$ \\
72 & 100 & $85.49 \pm 0.37$ & $60.94 \pm 0.33$ & $51.4 \pm 0.54$ & $44.97 \pm 0.75$ & $38.09 \pm 1.4$ \\
\hline
\end{tabular}

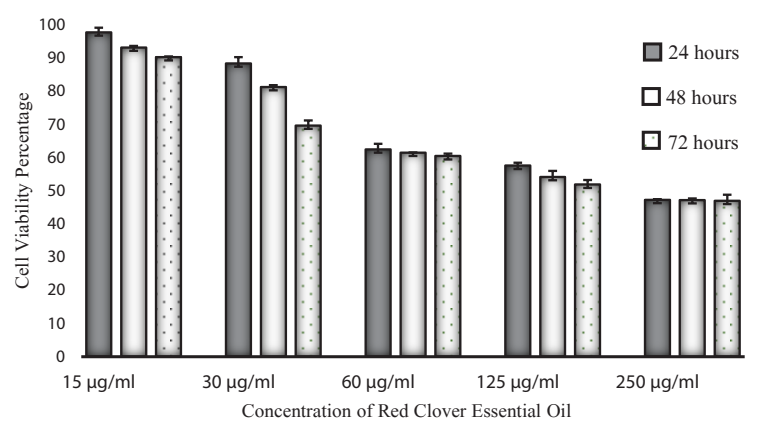

Figure 2: The Results of One of the Triplicate MTT Tests. Results show the toxicity effects and cell death of red clover's essential oil in $30 \mu \mathrm{g} / \mathrm{mL}$ concentration in a dose- and time-dependent manner, which is significant $(\mathrm{P}<0.05)$, but in higher concentrations of 60,125 and $250 \mu \mathrm{g} / \mathrm{mL}$, the decrease in cell viability is only dose-dependent.

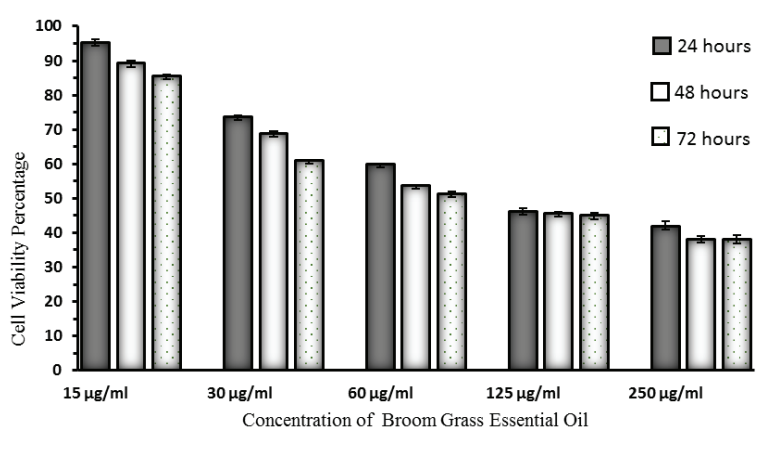

Figure 3: The Results of One of the Triplicate MTT Tests.

Results show the toxicity effects of essential oils of k. scoparia in $30 \mu \mathrm{g} / \mathrm{mL}$ concentration in a dose- and time-dependent manner, which is significant $(\mathrm{P}<0.05)$ but in higher concentrations of 60 , 125 , and $250 \mu \mathrm{g} / \mathrm{mL}$, cell viability reduction is dose-dependent only.

(light absorbance of cells treated with red clover's essential oil)/(the average of light absorbance in control cells $) \times 100$

\section{Essential Oil of K. scoparia Induced Cell Death in MCF-7 Cells}

The viability of MCF-7 cells was examined by the MTT assay after the treatment of MCF-7 cells with different concentrations of the essential oil of Bassia scoparia for 24,48 , and 72 hours, as presented in figure 3 . As shown in this figure, the cytotoxic effects of essential oil of $K$. scoparia on MCF-7 cells were dose- and time-dependent, which was similar to the results of the cell viability assay of MCF-7 cells treated with red clover essential oil. Moreover, it was revealed that the percentage of dead cells was significantly increased $(\mathrm{P}<0.05)$ at 15 and $30 \mu \mathrm{g} / \mathrm{mL}$ concentrations of essential oil of K. scoparia. The results of one of the triplicate tests of the MTT assay have shown in Table 3 as mean \pm SD. As shown in figure 3 and Table 4, the mean cell viability was significantly decreased by increasing concentrations of essential oils up to 60,125 , and $250 \mu \mathrm{g} / \mathrm{mL}$, while increased incubation time in these concentrations did not significantly change the mean cell viability. Furthermore, the $125 \mu \mathrm{g} / \mathrm{mL}$ concentration of $K$. scoparia essential oil is the minimum inhibitory concentration (IC50) value of MCF-7 cells proliferation. The percentage of viable cells treated with the essential oil of $K$. scoparia was calculated using the above formula.

\section{DISCUSSION}

Recently, many studies have been conducted to evaluate the anticancer effects of various essential oils and extracts, all of which demonstrate the ability of such compounds to inhibit the growth of a wide range of pathogenic microorganisms and food spoilage agents, as well as other factors affecting tumor growth. Because these compounds are completely natural, they have much less harmful effects on human health and environment as compared with chemical agents [8]. Iran has the history of several thousand years of civilization and a rich Islamic culture as well as a unique geograph- 
ic location where a large number of plant species can be grown. The number of plant species in Iran is five times that of the whole European continent [9]. In general, 11,000 plant species have been identified and collected from Iran, which are classified in 180 families and 1200 genera and could be considered as one of the richest sources available for health and economic aspects [10]. In this study, essential oils of red clover and Bassia scoparia fruit were used to assess their antitumor and antitoxic effects on MCF-7 breast cancer cells. Different studies have been conducted to examine the effect of essential oil of Bassia scoparia on apoptosis induction as well as its effects on preventing the proliferation of different cancer cells, including breast cells, oral squamous cell carcinoma (OSCC) cell line and hematologic malignancies such as Hodgkin's lymphoma. These studies demonstrated the antitumor and inhibitory effects of the essential oil of $K$. scoparia fruit on the proliferation of cancer cells. The present study showed the antitumor and antitoxic effects of essential oils of red clover and Bassia scoparia on MCF-7 cells. The analysis of essential oils of the plants indicated that the most frequent components in the essential oil of $K$. scoparia included $\alpha$-thujaplicine, phytoene, and butylated hydroxytoluene, dictamnol, phytol, and n-docosane. In addition, the most frequent compounds in red clover included hexanal, 2-ethyl furan, 2-methyl-2,4-hexadiene, and cyclopentanol. Biljana Kaurinovic et al. identified $\beta$-myrcene ( $4.55 \%)$, p-cymene (3.59\%), limonene $(0.86 \%)$ and tetrahydroionone $(1.56 \%)$ as the most frequent compounds in red clover [11]. Examining the results of mean cell viability using the MTT method reveals the sensitivity of MCF-7 cancer cells to essential oils of red clover and K. scoparia fruit. In similar studies, the cytotoxic effect of essential oil of $K$. scoparia on MDA-MB-231 cancer cells (breast cancer cell line) and oral squamous carcinoma cell line (OSCC) has been shown by Hey-yeon et al. [6]. Mazzio and Soleiman found the antitumor effect of the essential oil of K. scoparia in their study [12]. Furthermore, a study by Hey Yeon et al. on the effect of essential oil of K. scoparia on the morphology of MDA-MB-231 cells showed morphological changes similar to apoptotic cells, including vacuolation, cytoplasmic and cellular shrinkage as well as pyknotic nuclei. These changes were also observed in the present study on MCF-7 cells treated with essential oils of red clover and K. scoparia fruit. Morphological changes and apoptotic characteristics in MCF-7 calls were reinforced by increasing concentrations of essential oils of red clover and K. scoparia as well as increasing incubation time. Han H-Y et al. showed that the essential oil of $K$. scoparia fruit prevents cell cycle by arresting the G1 phase of cell cycle, which in turn decreases the percentage of viable cells [6]. As we know, reactive oxygen species (ROS) are the intrinsic activators of apoptosis capable of activating apoptosis from the extrinsic path. Han H-Y et al. indicated that the essential oil of
K. scoparia fruit significantly increased the ROS levels. They believed that an increase in intrinsic ROS triggers both intrinsic and extrinsic apoptosis pathways and prevents cell cycle. Furthermore, Wang et al. reported that Momordin IC, a triterpenoid-rich saponin in different medicinal plants, including K. scoparia, has antitumor effects in HepG2 cells [13]. Han H-Y et al. also stated in their study that further research on the effective factors present in the fruit of this plant, such as Mormordin (), which also exist in other plants like M. balsamina and Ampelopsis radix [14], can raise K. scoparia as a useful herbal medicine in treating or preventing breast cancer. Chen et al. showed that treating cancer cells with demethylated cantharidin from (NCTD) P21 resulted in 3-caspase inhibitor activation, which consequently led to apoptosis in HepG2 cells [15].

Based on our findings, the essential oils of red clover and K. scoparia inhibit the proliferation of the MCF-7 breast cancer cell line. In this regard, further studies will be helpful to understand possible molecular apoptotic mechanisms of essential oils of red clover and K. scoparia and to identify other major compounds in these plants as well as their potential antitumor characteristics.

\section{ACKNOWLEDGMENTS}

This study was financially supported by the vice-chancellor of research, Boroujerd Islamic Azad University, Lorestan, Iran.

\section{CONFLICT OF INTEREST}

The authors declared that they have no conflict of interest.

\section{ETHICS APPROVAL}

The use of cell lines in this study does not involve ethical considerations.

\section{REFERENCES}

1. Vo AT, Millis RM. Epigenetics and breast cancers. Obstet Gynecol Int. 2012;2012:602720. DOI: 10.1155/2012/602720 PMID: 22567014

2. Pathy NB, Yip CH, Taib NA, Hartman M, Saxena N, Iau P, et al. Breast cancer in a multi-ethnic Asian setting: results from the Singapore-Malaysia hospital-based breast cancer registry. Breast. 2011;20 Suppl 2:S75-80. DOI: 10.1016/j. breast.2011.01.015 PMID: 21316967

3. Tucak M, Popović S, Čupić T, Krizmanić G, Španić V, Meglič V, et al. Assessment of red clover (Trifolium pratense L.) productivity in environmental stress. Poljo Privreda. 2016;22(2):3-9.

4. Du WH, Tian XH, Yue Y, Lu J. Isoflavone content in red clover (Trifolium pratense L.) as related to nitrogen and phosphorus application rate. Chil J Agricult Res. 2013;73(4):372-6. DOI: $10.4067 /$ S0718-58392013000400007

5. Kafi M, Salehi M. Kochia Scoparia as a Model Plant to Explore the Impact of Water Deficit on Halophytic Communities. Pakistan J Botan. 2012;44:257-62.

6. Han HY, Kim H, Son YH, Lee G, Jeong SH, Ryu MH. Anti-cancer effects of Kochia scoparia fruit in human breast can- 
cer cells. Pharmacogn Mag. 2014;10(Suppl 3):S661-7. DOI: 10.4103/0973-1296.139812 PMID: 25298688

7. Han HY, Lee HE, Kim HJ, Jeong SH, Kim JH, Kim H, et al. Kochia scoparia induces apoptosis of oral cancer cells in vitro and in heterotopic tumors. J Ethnopharmacol. 2016;192:43141. DOI: 10.1016/i.jep.2016.09.019 PMID: 27616033

8. Khandelwal KR. Practical pharmacognosy: Pragati Books Pvt. Ltd.; 2008.

9. Omidbeygi M, Barzegar M, Hamidi Z, Naghdibadi H. Antifungal activity of thyme, summer savory and clove essential oils against Aspergillus flavus in liquid medium and tomato paste. Food Cont. 2007;18(12):1518-23. DOI: 10.1016/j. foodcont.2006.12.003

10. Lambert RJ, Skandamis PN, Coote PJ, Nychas GJ. A study of the minimum inhibitory concentration and mode of action of oregano essential oil, thymol and carvacrol. J Appl Microbiol. 2001;91(3):453-62. PMID: 11556910

11. Vlaisavljevic S, Kaurinovic B, Popovic M, Djurendic-Brenesel M, Vasiljevic B, Cvetkovic D, et al. Trifolium pratense L. as a potential natural antioxidant. Molecules. 2014;19(1):713-25.
DOI: 10.3390/molecules19010713 PMID: 24402202

12. Mazzio EA, Soliman KF. In vitro screening for the tumoricidal properties of international medicinal herbs. Phytother Res. 2009;23(3):385-98. DOI: 10.1002/ptr.2636 PMID: 18844256

13. Wang J, Yuan L, Xiao H, Xiao C, Wang Y, Liu X. Momordin Ic induces HepG2 cell apoptosis through MAPK and PI3K/Akt-mediated mitochondrial pathways. Apoptosis. 2013;18(6):751-65. DOI: $10.1007 / \mathrm{s} 10495-013-0820-\mathrm{Z}$ PMID: 23417763

14. Matsuda H, Li Y, Yamahara J, Yoshikawa M. Inhibition of gastric emptying by triterpene saponin, momordin Ic, in mice: roles of blood glucose, capsaicin-sensitive sensory nerves, and central nervous system. J Pharmacol Exp Ther. 1999;289(2):729-34. PMID: 10215646

15. Chen YN, Chen JC, Yin SC, Wang GS, Tsauer W, Hsu SF, et al. Effector mechanisms of norcantharidin-induced mitotic arrest and apoptosis in human hepatoma cells. Int J Cancer. 2002;100(2):158-65. DOI: $10.1002 / \mathrm{ijc} .10479$ PMID: 12115564 